\title{
FTIR-METABOLOMICS TO CORRELATE SORGHUM'S CHEMICAL PROFILE AND HCT-116 CYTOTOXICITY CHANGES DURING RICE-ANALOGUE PRODUCTION
}

\author{
[Metabolomik Berbasis FTIR untuk Mengkorelasikan Perubahan Profil Kimia Sorgum dan \\ Sitotoksisitasnya terhadap Sel kanker Kolon HCT-116 pada Pembuatan Beras Analog]
}

\author{
Nancy Dewi Yuliana ${ }^{1,2) \star}$, Endang Prangdimurti ${ }^{1,2)}$, and Didah Nur Faridah ${ }^{1,2)}$ \\ 1) Department of Food Science and Technology, Faculty of Agriculture Technology, Bogor Agricultural University, Bogor \\ ${ }^{2}$ Southeast Asian Food and Agricultural Science and Technology (SEAFAST) Center, Bogor Agricultural University, Bogor
}

Received March $19^{\text {th }} 2018$ / Accepted July $31^{\text {st }} 2018$

\begin{abstract}
Rice-analogue (RA) made from sorghum (Sorghum bicolor L. Moench) is recently popular in Indonesia due to its potential as an alternative staple food besides rice. Sorghum has many phytochemicals with various functional properties including those correlating with anticancer activity. The RA production involves several steps; i.e. polishing, milling, mixing, extruding, and oven drying. This study used FTIR based metabolomics to identify whether these steps affect sorghum phytochemicals composition and its cytotoxicity against HCT-116 cell lines in-vitro. It was discovered that the cytotoxic of sorghum was relatively stable during the process. The RA final product (oven dried RA) showed higher activity (90.85\%) as compared to other samples taken from previous steps (2000 ppm dose). The correlation between the FTIR profile and cytotoxic activity of RA was analyzed using one of the multivariate data analysis method namely orthogonal projection to the least square (OPLS). By comparing the OPLS data with FTIR data of compounds reported to be found in sorghum, it is shown that typical FTIR patterns for the phenolic compounds particularly ferulic acids, $p$-coumaric acid, and procyanidins, as well as phytosterols, were highly correlated with the RA's cytotoxic activity. The signals were found to be dominant in the most active sample (oven dried RA). It can be concluded that sorghum phytochemicals responsible for its cytotoxic activity were not affected by the processing steps, therefore RA is potential to be promoted as an alternative functional staple food in Indonesia.
\end{abstract}

Keywords: colon cancer, FTIR metabolomics, HCT-116 cells, rice analogue, sorghum

\begin{abstract}
ABSTRAK
Beras-analog (RA) yang terbuat dari sorgum (Sorghum bicolor L. Moench) merupakan salah satu produk baru yang populer di Indonesia karena potensinya sebagai makanan pokok alternatif selain nasi. Sorghum kaya akan kandungan fitokimia yang memiliki aneka sifat fungsional termasuk senyawa dengan aktivitas antikanker. Produksi RA melibatkan beberapa langkah; penyosohan sorgum, penepungan, pencampuran, ekstrusi, dan pengeringan oven. Penelitian ini menggunakan metabolomics berbasis FTIR untuk mengidentifikasi apakah langkah-langkah ini mempengaruhi komposisi fitokimia sorghum dan aktivitas sitotoksisitasnya terhadap galur sel kanker kolon HCT-116 in-vitro. Ditemukan bahwa aktivitas sitotoksik sorgum relatif stabil selama proses pengolahan. Produk akhir RA (beras analog yang telah dikeringkan dengan oven) menunjukkan aktivitas yang lebih tinggi (90,85\%) dibandingkan sampel lain yang diambil dari langkah sebelumnya (dosis 2000 ppm). Korelasi antara profil FTIR dengan aktivitas sitotoksik RA dianalisis dengan menggunakan salah satu metode analisis data multivariat yaitu proyeksi ortogonal sampai kuadrat terkecil (OPLS). Analisis OPLS menghasilkan beberapa bilangan gelombang yang berkorelasi positif dengan aktivitas sitotoksik, selanjutnya hasil dibandingkan dengan data FTIR senyawa yang dilaporkan ditemukan pada sorgum. Pola FTIR yang khas untuk senyawa fenolik terutama asam ferulik, asam pcoumaric, dan procyanidins, serta fitosterol, sangat berkorelasi dengan aktivitas sitotoksik RA. Bilangan gelombang tersebut ditemukan dominan pada sampel yang paling aktif (produk akhir). Dapat disimpulkan bahwa fitokimia sorgum yang berperan pada aktivitas sitotoksik tidak terpengaruh oleh proses pengolahan, oleh karena itu RA berpotensi untuk dipromosikan sebagai makanan pokok fungsional alternatif di Indonesia.
\end{abstract}

Kata kunci: beras analog, HCT-116, kanker kolon, metabolomik FTIR, sorgum

*Penulis Korespondensi:

E-mail: nancy_dewi@ipb.ac.id 


\section{INTRODUCTION}

Sorghum based rice-analogue developed by Bogor Agricultural University has recently been popular in Indonesia for its potential contribution in Food Diversification Program promoted by Indonesian Government (Budijanto and Yuliana, 2015). Sorghum (Sorghum bicolor L. Moench) was chosen for its good nutritive composition, particularly high content of carbohydrate, therefore suitable to be used as a staple food, as well as unique phytochemicals which may contribute to sorghum various biological activities. The link between high sorghum consumption and low incidence of several degenerative diseases has been reported in many studies. Previous study showed that sorghum inhibited the growth of colon cancer in Balb/c mice in vivo (Sadek et al., 2016). This result is expected to support the promotion of sorghum based rice-analogue as a rice substitute with some health benefits. However, previous study was conducted with fresh sorghum grain, while sorghum based rice-analogue production includes several steps such as polishing, milling, blending with other additives, hot extrusion, and oven drying. Metabolites composition of sorghum subjected to these processing steps may be changed, which may further affect its biological activities. A study on changes in phytochemical profiles of sorghum during the process of sorghum tea production and its correlation to several bioactivities of sorghum was previously reported (Wu et al., 2013). They found that different processing step led to the changes of different metabolites. Free ferulic and bound $p$-coumaric acids significantly increased during steaming while phenolic acids, total phenolics, total flavonoids, and procyanidins content were significantly higher after roasting as compared to soaking and steaming. It was also observed that the changes of total phenolics, total flavonoids, and procyanidins content were positively correlated with (DPPH) radical scavenging activity, $\alpha$-glucosidase, and $\alpha$-amylase inhibitory activities of the tea. Based on aforementioned reasons, the study on the effect of various processing steps to the phytochemical profiles of sorghum and whether the changes affect the anticancer activity of sorghum is very essential to conduct.

Metabolomics is defined as a systematic qualitative or quantitative study of all metabolites in a specific matrices, including elucidating the affecting factors (Verpoorte et al., 2005). Metabolomics can be applied to link the metabolite profile of natural product extract with its biological activity. Orthogonal projection to the least square analysis (OPLS) was found to be the most suitable tool to study the chemical profile-activity correlation (Yuliana et al., 2014). Concerning analytical tools to be used for metabolomics study, NMR is believed to be the most suitable one due to its high snapshot and reproducibility. However, high operational cost is the limitation, particularly in developing country like Indonesia. Fourier transform infrared spectroscopy (FTIR) is one of other potential alternative instrument to be used in metabolomics based study in Indonesia since it is more affordable than NMR. FTIR is a physicochemical method that differentiates functional groups based on vibration within them after absorbing infrared spectrum light. This method is able to quickly provide qualitative and quantitative metabolic fingerprint information with minimal or no sample preparation of complex biological matrices. Several metabolomics based studies by using FTIR have successfully been performed, including the one to correlate FTIR profile of orthosiphon stamineus different extracts to its antioxidant and $\alpha$-glucosidase inhibitor activity, thus typical wavenumbers of compounds responsible for the activity can be elucidated (Juliani et al., 2016).

The objectives of the reported study are to identify which processing step involved in the production of sorghum based rice-analogue significantly affecting the phytochemicals composition of sorghum, and which of those phytochemicals composition changes significantly affecting the anticancer activity of sorghum. The method to prepare sorghum based artificial rice was adapted from previous study (Budijanto and Yuliyanti, 2012). Sample was taken from each step and was divided into two; for metabolite profile analysis using FTIR and for cytotoxic analysis in vitro against human colon cancer cell HCT-116. Particular metabolites changes that significantly affected anticancer activity was elucidated by studying the correlation between these two blocks of data with OPLS.

\section{MATERIALS AND METHODS}

\section{Materials}

The main materials used in this study were sorghum (Kawali cultivar), which was kindly provided by PTPN XII Indonesia, modified cassava starch and glycerol monostearate were obtained from PT. Setia Guna Bogor Indonesia.

\section{Sorghum based rice-analogue production (Budijanto and Yuliyanti, 2012)}

Rice-analogue (RA) composition consisted of sorghum and modified cassava starch (mocaf) at 7:3 ratio (w/w), glycerol mono-stearate (GMS) and water were added at 2 and $50 \%$ from total flours weight respectively. Rice analogue production steps consisted of sorghum grains polishing, milling, mixing with other ingredients (water, modified cassava starch, glycerol monostearate), hot extrusion (80$\left.90^{\circ} \mathrm{C}\right)$, oven drying $\left(60^{\circ} \mathrm{C}, 2 \mathrm{~h}\right)$. A $500 \mathrm{~g}$ of sample 
was taken from each step including sorghum brans obtained from polishing step, extracted 3 times with 80\% methanol (@300 mL) (Merck, USA), then dried under vacuum. The extract was divided into two parts: for FTIR analysis and for cytotoxic activity analysis. The process was repeated twice. This step was performed at F-Technopark Pilot Lab and Food Chemistry Lab of Food Science and Technology Department, Faculty of Agricultural Engineering and Technology, Bogor Agricultural University.

\section{Fourier transformed infrared (FTIR) spectrosco- py analysis}

The chemical profile test of the sample was measured by instrument FTIR (Tensor 37, Bruker Optik GmbH, Germany) with DTGS (deuterated triglycine sulphate) detector using potassium bromide $(\mathrm{KBr})$ pellet technique in absorbance mode. A $90 \mathrm{mg}$ of KBr FTIR grade (Merck, USA) was crushed using mortar, mixed with $10 \mathrm{mg}$ of dried extract and homogenized using mortar. The mixture was placed on FTIR sample holder and scanned at $400-4000 \mathrm{~cm}^{-1}$. Analysis was performed in 2 replications in transmittance mode. The obtained spectrum is then processed with OPUS software version 4.2 (Bruker Optik $\mathrm{GmbH}$, Germany). FTIR spectra were normalized, baseline corrected, and then converted to commadelimited text prior statistical analysis. FTIR analysis was performed at Laboratory of Biopharmaca Research Center, Bogor Agricultural University.

Preparation and maintenance of HCT-116 cell culture (Kuo et al., 2004)

HCT-116 (ATCC CCL-247) cells (kindly provided by Stem Cell and Cancer Institute, Kalbe Farma, Indonesia) were seeded at a concentration of 2500 cells in $100 \mu \mathrm{L}$ of dulbecco's modified eagle medium (DMEM) (Merck, USA) growth medium (containing 10\% fetal bovine serum, $100 \mathrm{U} / \mathrm{mL}$ penicillin, and $100 \mathrm{ug} / \mathrm{mL}$ streptomycin 1\%) in 96 well-plate. Cells were incubated at $37^{\circ} \mathrm{C}$ temperature and $5 \% \mathrm{CO}_{2}$. Cytotoxic activity test was conducted after HCT-116 cells reached 50\% confluent (24 hours).

\section{Cytotoxic activity test against HCT-116 cell line} (ATCC CCL 246) (Kuo et al., 2004)

Colorimetric testing using 3-(4-,5-dimethylthiazol-2-yl)-2,5-diphenyl tetrazolium bromide (MTT) (Merck, USA) was used to determine HCT-116 cell viability. Cell cultures were transferred into 96 wellplates at $100 \mu \mathrm{L} /$ well, leaving 3 empty wells as media controls. The cell condition was observed using a microscope. Plates that already contain sufficient cells were taken out from the $\mathrm{CO}_{2}$ incubator. The cell medium is then discarded (the plate is reversed $180^{\circ} \mathrm{C}$ ) and wash by $100 \mu \mathrm{L}$ PBS (Phosphate Buffer Saline) (Merck, USA) twice. Next, $100 \mu \mathrm{L}$ RA extract concentration at the dose of $10,500,1000,5000$ ppm was added. Control well was only filled by the complete culture medium. The culture was incubited at incubator with condition of $5 \% \mathrm{CO}_{2}, 37^{\circ} \mathrm{C}$, and $\mathrm{RH} 90 \%$ for 48 hours. After 48 hours, $10 \mu \mathrm{L}$ tetrazolium salt reagent (MTT) at concentration of $5 \mathrm{mg} / \mathrm{mL}$ complete Roswell Park Memorial Institute (RPMI) 1640 (Merck, USA) was added to each microplate well. After 4 hours of incubation, $80 \mu \mathrm{L}$ of $0.04 \mathrm{~N} \mathrm{HCl}$ (Merck, USA) solution in isopropanol was added to each well. Optical density measurements were read using a microplate reader at $\lambda 545 \mathrm{~nm}$ (Epoch Microplate Spectrophotometer, BioTek ${ }^{\circledR}$ Instruments Inc., USA). All stages are done in triplo. The absorbance data of the treatment is calculated by this formula:

$\%$ Inhibition $=(1-O D$ sample/OD control $) \times 100 \%$

where, $\mathrm{OD}=$ Optical density (Absorbance) at $\lambda 595$ $\mathrm{nm}$

\section{Orthogonal projection to the least square (OPLS) analysis}

In this study the FTIR spectrum represents the chemical profile of the RA methanolic extract, which is then used as the $X$ data matrix, while the cytotoxic activity is used as $Y$ data matrix. Data were analyzed by OPLS using SIMCA-P software version 13.0 (Sartorius Stedim Biotech) with pareto scaling. The model is described with criteria of model precision (R2Y) and prediction accuracy (Q2Y). The model is then validated with CV ANOVA and permutation test. The wave number area contribute the most to the bioactivity was selected base on the value of $Y$ relative coefficient and variable of importance (VIP).

\section{RESULTS AND DISCUSSION}

\section{Artificial rice products}

Rice analogue was made in 5 main steps as previously mentioned in material and method section. In Figure 1, the pictures of sorghum and RA samples taken from every step are presented. Totally there are 6 samples taken from one batch, namely fresh sorghum, sorghum brans, polished and milled sorghum (in the form of sorghum flour), sorghum dough mixed with other RA ingredients (modified cassava starch, glycerol mono-stearate, and water), extruded RA, and oven dried RA. As sorghum subjected to different treatments, it was expected that sorghum chemical composition was also changed accordingly. In the milling process, sorghum was separated from its bran. The brans were removed since it might give bitter taste to the RA final product due to its tannin content. Sorghum brans were reported to contain phenolic acids such as gallic acid, $p$-hydroxybenzoic acid, protocatechuic 
acid and catechin (Burdette et al., 2010). This phenolic compounds were thought to associate with a range of bioactivities of sorghum including antioxidant anti-inflammatory activity (Bralley et al., 2008). It is suspected that after milling, sorghum's bioactive compounds content might be decreased, since sorghum grains are primarily composed of starch, which consist of approximately $20-30 \%$ of amylose and $45-54 \%$ of amylopectin (w/w, fresh weight basis).

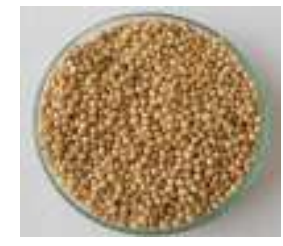

A

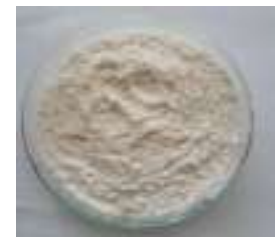

D

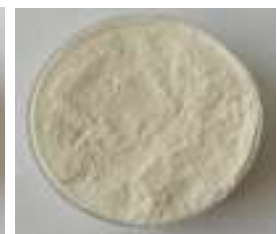

B

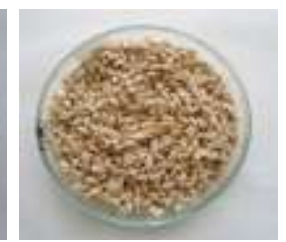

$E$

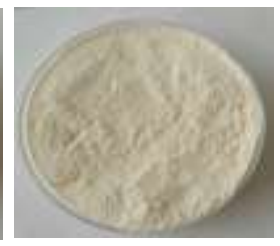

C

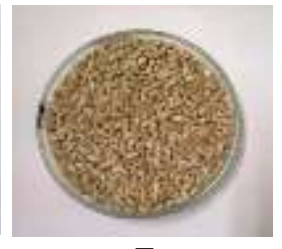

$\mathbf{F}$
Note: $A=$ fresh sorghum; $B=$ sorghum brans taken from polishing step; $\mathrm{C}=$ sorghum flour taken from milling step; $D=R A$ dough taken from mixing step; $E=$ extruded RA taken from extrusion step; and $F=$ oven dried RA taken from oven drying step

Figure 1. Samples taken from each steps involved in sorghum based artificial rice production

In the next step (mixing), sorghum was mixed with modified cassava starch, glycerol monostearate, and water. These additional ingredients are important to get RA with shape similar to paddy rice. For example, glycerol monostearate had a function as binding agent. The last steps were extrusion and oven drying. Here RA dough was directly exposed to heat $\left(80-90^{\circ} \mathrm{C}\right.$ during extrusion and $100^{\circ} \mathrm{C}$ during oven drying). The treatments is needed to reduce water content of the rice so it has longer shelflife, but the process might also destroy some of health beneficial compounds, thus the activity might also be reduced.

\section{HCT-116 cytotoxic activity of sorghum and RA extracts}

Cancer is the first leading cause of death in developed countries and the second in developing countries. Adoption of cancer-associated lifestyles such as smoking, physical inactivity, and 'westernized' diet, is one of the factors for increasing cancer occurrence in the last group of countries. Fifty-six percent of the cancer cases and $64 \%$ of cancer related-death occurred in the developing countries, most probably because of late stage diagnosis and limited access to a proper treatment (Jemal et al., 2011). In this situation, preventive action by promoting healthy lifestyle including eating healthy food can be one of the better options to reduce cancer occurrence. The present study was the an initial research to develop functional RA which has an ability to prevent colon cancer.

HCT-116 cytotoxic activity profile of sorghum and RA sample extracts taken from each step during RA production process can be seen in Table 1. The tested dose was 2000 ppm which was obtained after several trials using different concentration as previously mentioned in method section. Concentration of 2000 ppm was chosen as it showed minimum toxicity to the normal cells. It was shown that the cytotoxic activity of fresh sorghum and sorghum bran was reduced after polishing and milling steps but then increased again in the next three consecutive steps and surprisingly reached the highest activity after oven drying. Analysis on RA chemical composition profile is necessary to conduct to identify which compounds were affected by the processing steps which associated with RA cytotoxicity profile.

Table 1. HCT 116 cytotoxic activity of sorghum and RA extracts

\begin{tabular}{lc}
\hline \multicolumn{1}{c}{ Samples } & \% Cytotoxic Activity at $2000 \mathrm{ppm}$ \\
\hline Fresh sorghum & $83.4 \pm 8.4$ \\
Sorghum brans & $84.9 \pm 1.7$ \\
Milled sorghum & $81.9 \pm 12.8$ \\
Mixing dough & $85.8 \pm 10.4$ \\
Extruded rice & $87.4 \pm 3.2$ \\
Oven dried rice & $90.8 \pm 5.1$ \\
\hline Note: The value was the mean of two measurements, \\
each conducted in triplo
\end{tabular}

\section{FTIR spectra representative of sorghum and AR samples}

In this study fourier transform infrared (FTIR) spectroscopy was used to provide chemical profile of RA. FTIR was reported to be suitable for metabolomics based analysis which needs a quick, easy, robust, and non-destructive sample preparation (Pop et al., 2014). Metabolomic-based FTIRs were sensitive enough to be used to evaluate changes in fruit metabolites over various seasons (Hossain et al., 2009) and harvesting time (Yusof et al., 2015).

Figure 2 showed the 12 FTIR spectra taken from 6 sampling points of RA production, each was taken in duplo. There was almost no visible differrence when we compared the spectra visually. All spectra showed nearly similar bands with different intensities at $3300 \mathrm{~cm}^{-1}, 2800-3000 \mathrm{~cm}^{-1}, 1200-1700$ $\mathrm{cm}^{-1}, 860-1000 \mathrm{~cm}^{-1}$, and $500-600 \mathrm{~cm}^{-1}$. These wavenumbers associate with various types of functional groups belong to different phytochemicals present in sorghum and other ingredients used to produce RA. For example, spectra 1-4, which representing chemical profile of fresh sorghum and sor- 
ghum brans, had broader peaks at $3000-3200 \mathrm{~cm}^{-1}$ than others. This area might be associated with $\mathrm{O}-\mathrm{H}$ stretching from alcohol. FTIR peak at $1600 \mathrm{~cm}^{-1}$ seems to be higher in spectra 1-7, which representing fresh sorghum, sorghum brans, and sorghum flour before the mixing step. This area might be associated with $\mathrm{C}=\mathrm{C}$ stretching from monosubstituted alkene or unsaturated ketone groups. We could not correlate these small visual differences with activity profile of each samples. To extract more information from the spectral data, we converted the spectra into excel files and used it as an input for OPLS analysis. In OPLS analysis, FTIR signals act as $X$ variables while HCT-116 cytotoxic activities (in $\%)$ act as $Y$ variables.

\section{OPLS analysis result of sorghum and AR sam- ples}

OPLS was used in this study to see the correlation between chemical profiles of samples with its anticancer activity. In principle, OPLS tries to correlate two types of matrix data, i.e. data in the chemical composition of sample $(X)$ and sample activity data $(Y)$. There are several OPLS outputs that can be used to interpret data including score plot and loading biplot. The OPLS score plot showed how the tested samples being clustered according to their activity profile, while loading biplot shows both samples clustering and what compounds, or here is the FTIR wavenumbers, are abundant in samples with good activity or low activity profile.

As can be seen in Figure $3 \mathrm{~A}$ (the score plot), RA samples with higher activity value (F21, P21, E21, M21, O21, all had activity value of $89 \%$ or higher) are grouped in the right side of score plot, while others are grouped in the left side of the plot.
Based on their location in Figure 3B (the loading biplot), the wavenumber between $3834-2403 \mathrm{~cm}^{-1}$, $1793-900 \mathrm{~cm}^{-1}$, and $873-393 \mathrm{~cm}^{-1}$ come from functional groups of compounds abundant in active samples. These wavenumbers were compared with previously reported FTIR data for compounds reported found in sorghum. Including in this area are typical spectra for ferulic acid and $p$-coumaric acid between $650-1500 \mathrm{~cm}^{-1}$ (Holser, 2012), procyanidins 3500 $\mathrm{cm}^{-1}, 2836-3062 \mathrm{~cm}^{-1}$, and 698-1600 $\mathrm{cm}^{-1}$ (Dennis et al., 2012). These compounds were previously reported to increase during the process of sorghum tea production (Wu et al., 2013). The wide band at $400-3500 \mathrm{~cm}^{-1}$, the band at 2800-2900 $\mathrm{cm}^{-1}$, and $900 \mathrm{~cm}^{-1}$, revealed the presence of phytosterols (Yang et al., 2010). Since the portion of sorghum is smaller after mixing with other RA ingredients (modified cassava and glycerol mono-stearate) while its anticancer activity was the highest after the last step (oven drying) than that of sorghum or sorghum bran alone in previous steps, it can be concluded that RA processing tended to increase anticancer activity of sorghum.

During RA making process especially in extruding and oven drying steps, sorghum was subjected to heat. This treatment might release phytochemicals from its matrix therefore it increased RA cytotoxic activity. Extrusion process involves the use of high temperature and high pressure which might release phytochemicals from its matrix therefore rising the activity. The influence of extrusion to the bioactive compounds and the antioxidant capacity was previously reported. Rye grains subjected to extrusion condition of $120^{\circ} \mathrm{C} / 20 \%$ humidity and $180^{\circ} \mathrm{C} /$ $14 \%$ humidity contained higher polyphenol levels as compared to raw grains.

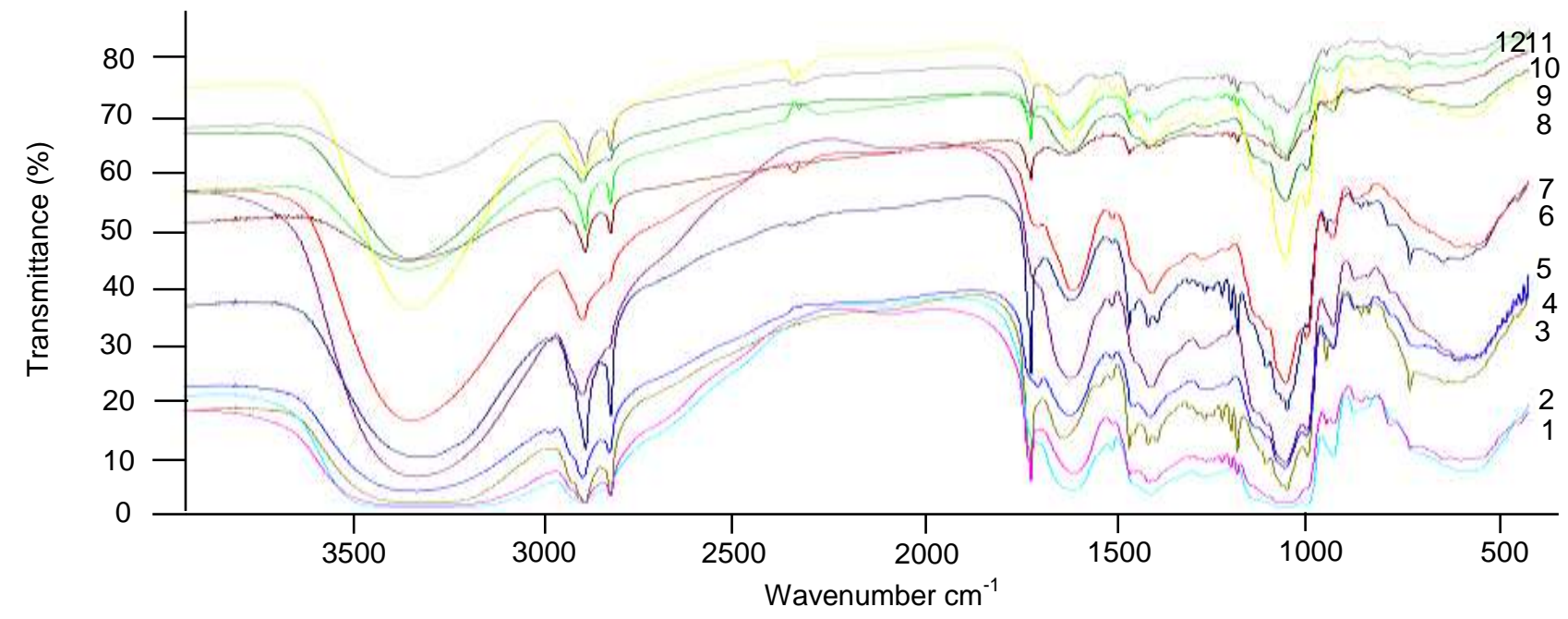

Note: $1-2$ = fresh sorghum; 3-4 = sorghum brans; 5-6 = sorghum flour taken from milling step; 7-8 = RA dough taken from mixing step; 9-10 = extruded RA taken from extrusion step; 11-12 = oven dried RA taken from oven drying step

Figure 2. FTIR spectra representative of samples taken from each RA processing step. Samples were taken twice. Each two adjacent colorful lines representing one processing step started from the bottom of the spectra 

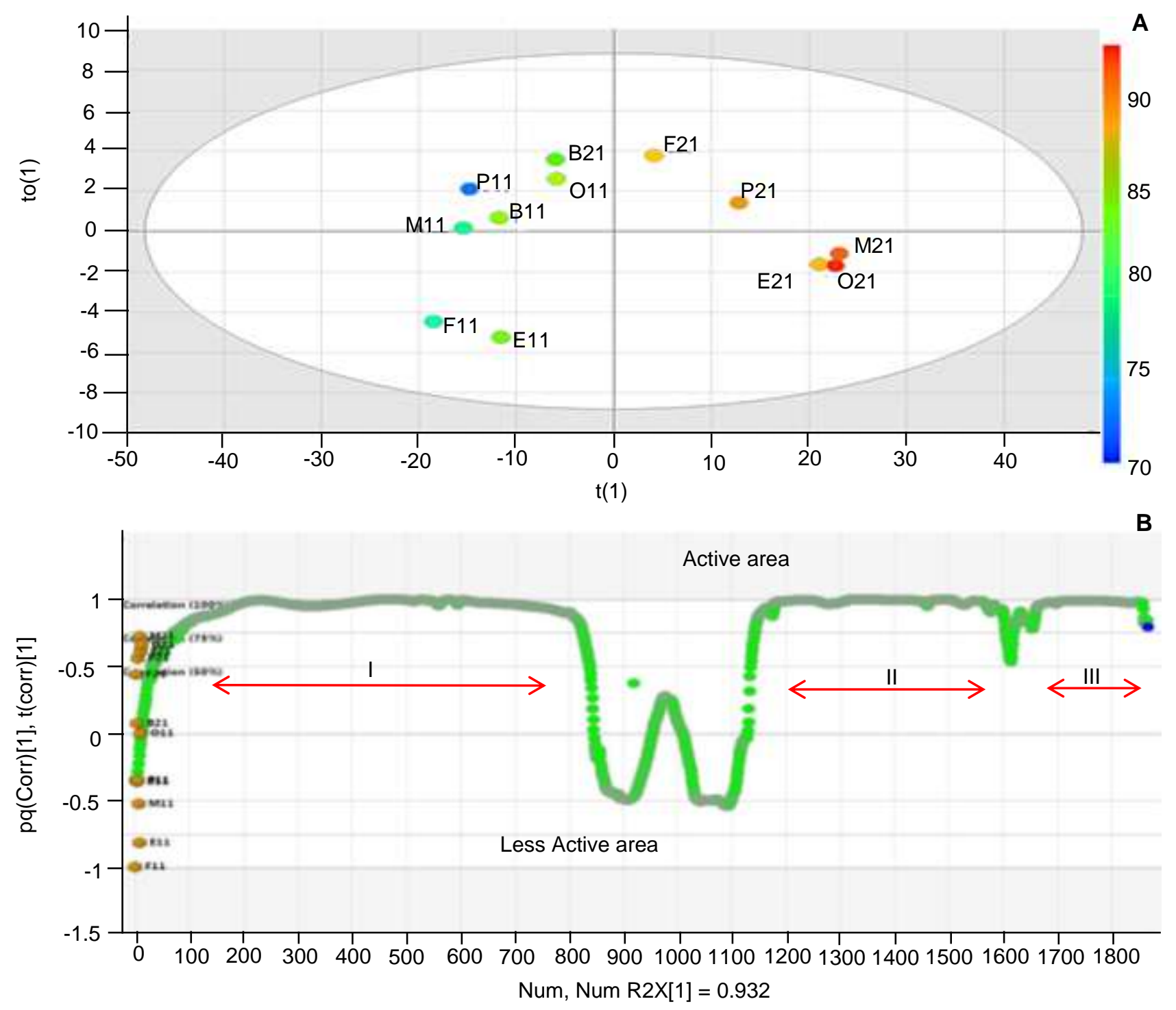

Note: $=\mathrm{X} ; \boldsymbol{\nabla}=\mathrm{Y} ; \mathbf{=}=\mathrm{t}($ corr $)[1]$

Figure 3. $A=$ OPLS score plot sorghum based RA methanolic extract; $B=$ OPLS Loading Bi-Plot sorghum based RA methanolic extract FTIR data. $F=$ fresh sorghum; $B=$ sorghum bran; $P=$ polished and milled sorghum; $M=$ Mixed RA; $E=$ Extruded RA; $O=$ Oven dried RA, numbers represent replications. Color gradient from blue to red in score plot represent an increase of cytotoxic inhibition activity. Wavenumbers situated nearby the active samples (top of the plot) are those which have strong contribution to RA cytotoxic activity, those are area I $=3834-2403 \mathrm{~cm}^{-1}, \mathrm{II}=1793-900 \mathrm{~cm}^{-1}$, III = 873-393 $\mathrm{cm}^{-1}$

The authors assumed that these were probably as the effect of heating which stimulating polyphenols release from grain cell walls during the process. Antioxidant activity of extruded grains was also found to be significantly elevated as compared to raw grain (Gumul et al., 2010). Ferulic acid, $p$-coumaric acid, and procyanidin were previously reported to increase during the process of sorghum tea production (Wu et al., 2013). On another study, the level of soluble phenolic acids were also significantly increased after sorghum cooking process (N'Dri et al., 2013).
Another tool to extract information from OPLS analysis is Y-related coefficient plot. It is shown in Figure 4. In this plot, FTIR wavenumbers with positive correlation value (marked with red arrow) can be observed. Those signals are: the peak of $3300-3500$ $\mathrm{cm}^{-1}(-\mathrm{OH}), 3010-3050 \mathrm{~cm}^{-1}$ (aromatic C-H), 2800$2900 \mathrm{~cm}^{-1}, 1700-1725$ (C=O, carboxyl group), 1450$1600 \mathrm{~cm}^{-1}$ (C=C, aromatics), $1000-1300 \mathrm{~cm}^{-1}$ (C-O, carboxyl group). The distribution of these important signals over the RA samples can be observed by using $X$-variant (X-var) plot for each respective peak (Figure 5). 


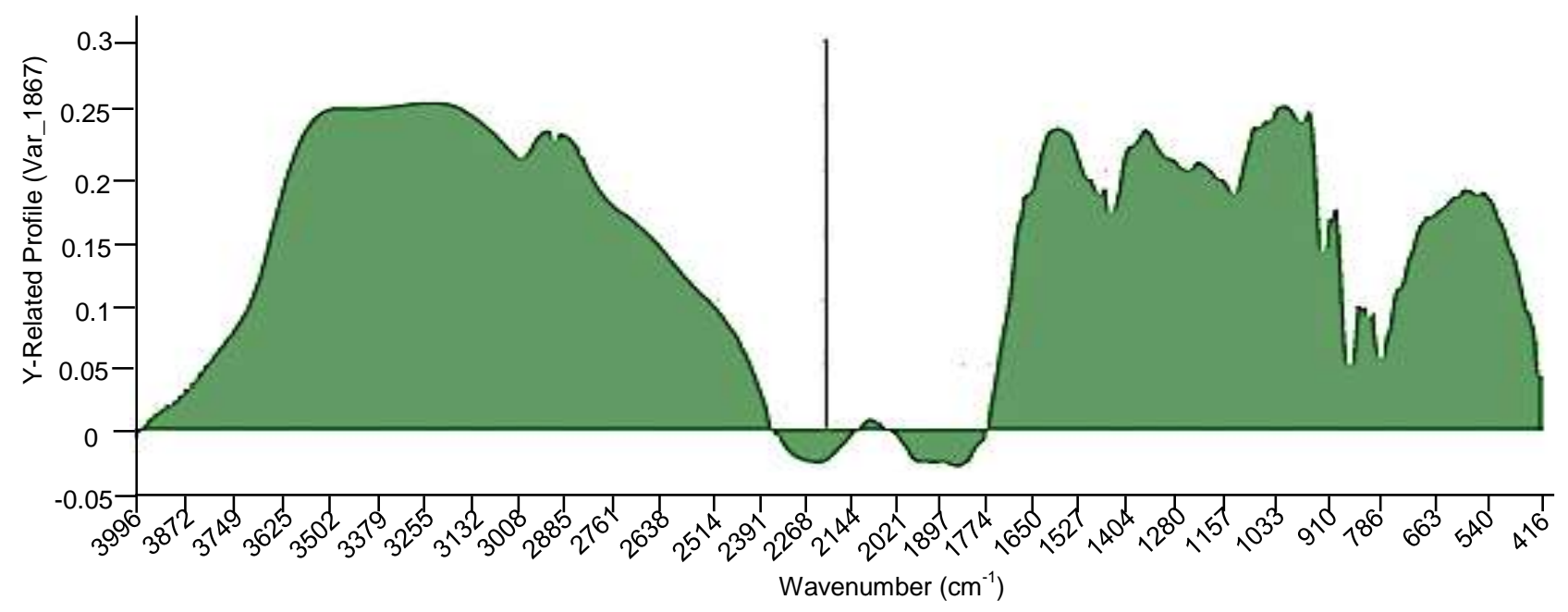

Figure 4. OPLS Y-related coefficient plot of RA methanolic extract FTIR profile and its cytotoxic activity against HCT-116 cells. Wavenumber with positive Y-related coefficient value $(>0.5)$ had strong contribution to the activity, while negative $\mathrm{Y}$-related coefficient value means the opposite role
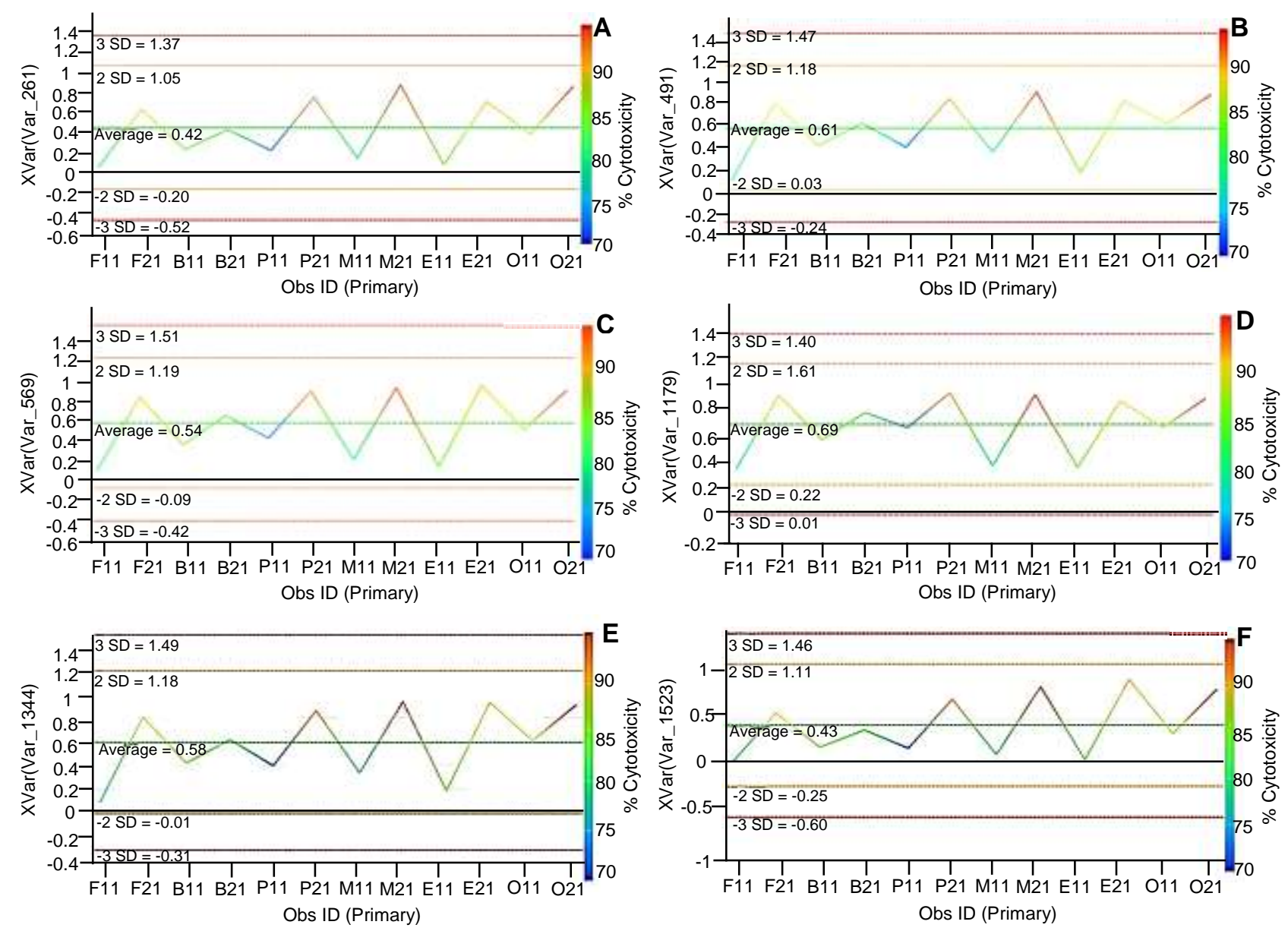

Figure 5. OPLS X-var plot of RA FTIR profile and its cytotoxic activity against HCT-116 cells. The plot showed information on the distribution of signals with positive Y-related correlation value over the samples. Colour gradient from blue to red represent higher to lower cytotoxic activity. Six wavenumbers were chosen: A. X-var plot of $3500 \mathrm{~cm}^{-1}$ wavenumber B. X-var plot of $3050 \mathrm{~cm}^{-1}$ wavenumber C. X-var plot $2900 \mathrm{~cm}^{-1}$ wavenumber D. X-var plot of $1725 \mathrm{~cm}^{-1}$ wavenumber E. Xvar plot of $1400 \mathrm{~cm}^{-1}$ wavenumber F. X-var plot of $1050 \mathrm{~cm}^{-1}$ wavenumber 
It is observed that the peaks are abundant in samples with higher cytotoxic activity (marked by red colour in Figure 5). The signals were found to be higher in samples taken from mixing, extrusion, and oven steps as compared from others. Previous studies elsewhere reported the presence of ferulic acid, $p$-coumaric acid, procyanidins, and phytosterols as active compounds found in sorghum. By comparing with previously reported FTIR data for the respective compounds, the aforementioned signals probably correlate with the presence of ferulic acid, $p$-coumaric acid, procyanidins, and phytosterols in the active AR extracts.

Phenolic compounds are believed to highly contribute to sorghum's biological activity. They show an antioxidant effect by donating hydrogen radicals and/or scavenging free radicals, thus may have protective effect against degenerative diseases, such as cancer and cardiovascular disease. Administration of ferulic acid and $p$-coumaric acid were shown to inhibit cell cycle progression in human colon cancer cell line $\mathrm{CaCO}_{2}$ (Janicke et al., 2011).

Phytosterol was reported to be more resistant to heat thus may contribute to the activity of the active RA extracts (Menéndez-Carreño et al., 2011). Among all types of phytosterol, the three major sterols found in sorghum are sitosterol, campesterol, and stigmaterol (Leguizamón et al., 2009). Zbasnik et al. (2009) determined the significant antiproliferative effect of grain sorghum (GS) dry distiller's grain (DDG) lipids in Caco-2 cells. Characterization of GSDDG lipid shows the presence of phytosterol (predominantly campesterol and stigmasterol), as well as vitamin $\mathrm{E}$ (predominantly $\mathrm{Y}$-tocopherol), triacylglycerides (predominantly linoleic acid), policosanols, and aldehydes, each of which may play sinergistic role that may be responsible for the cytotoxic activity properties.

\section{CONCLUSION}

Sorghum anti proliferative activity against HCT116 cell lines tended to increase during RA production. The final product obtained from the last step (oven drying) showed the highest activity as compared to the fresh one or others from previous processing steps. OPLS analysis of FTIR spectra and bioactivity data revealed that several wavenumbers had positive correlation with sorghum anti proliferative activity those are the band with wavenumbers of $3300-3500 \mathrm{~cm}^{-1}(-\mathrm{OH}), 3010-3050 \mathrm{~cm}^{-1}$ (aromatic C$\mathrm{H}), \quad 2800-2900 \mathrm{~cm}^{-1}, 1700-1725 \quad(\mathrm{C}=\mathrm{O}$, carboxyl group), $1450-1600 \mathrm{~cm}^{-1}(\mathrm{C}=\mathrm{C}$, aromatics), $1000-$ $1300 \mathrm{~cm}^{-1}$ (C-O, carboxyl group). These signals probably correlate with functional groups of several compounds previously reported to be present in sorghum extract (ferulic acid, $p$-coumaric acid, procya- nidins, and phytosterols). These signals were dominant in samples with higher anticancer activity. Heat introduced during RA making process might release the phytochemicals from the food matrix thus increased its anticancer activity.

\section{ACKNOWLEDGEMENT}

This research was generously funded by 2013 Indonesian Toray Science Foundation Research Grant.

\section{REFERENCES}

Budijanto S, Yuliana ND. 2015. Development of rice analog as food diversification in Indonesia. $\mathrm{J}$ Developments in Sustainable Agric 10: 7-14. DOI: $10.11178 /$ jdsa.10.7.

Budijanto S, Yuliyanti. 2012. Studi persiapan tepung sorgum (Sorghum bicolor L. Moench) dan aplikasinya pada pembuatan beras analog. J Teknol Pertanian 13: 177-186.

Burdette A, Garner PL, Mayer EP, Hargrove JL, Hartle DK, Greenspan, P. 2010. Antiinflammatory activity of selected sorghum (Sorghum bicolor) brans. J Med Food 13: 879-887. DOI: 10.1089/jmf.2009.0147.

Dennis EG, Jeffery DW, Johnston MR, Perkins MV, Smith PA. 2012. Procyanidin oligomers. A new method for $4 \rightarrow 8$ interflavan bond formation using C8-boronic acids and iterative oligomer synthesis through a boron-protection strategy. Tetrahedron 68: 340-348. DOI: 10.1016/j.tet.20 11.10 .039$.

Gumu D, Korus J, Czechowska K, Bartoń H, Fołta M. 2010. The impact of extrusion on the content of polyphenols and antioxidant activity of rye grains (Secale cereale L.). Acta Sci Pol Technol Aliment 9: 319-330.

Holser RA. 2012. Principal component analysis of phenolic acid. Int Scholarly Res Notices Spectroscopy 5: 1-5. DOI: 10.5402/2012/493203.

Hossain MA, Rahman SMM. 2015. Isolation and characterisation of flavonoids from the leaves of medicinal plant Orthosiphon stamineus. Arab J Chem 8: 218-221. DOI: 10.1016/j.arabjc.2011. 06.016 .

Janicke B, Hegardtb C, Kroghc M. 2011. The antiproliferative effect of dietary fiber phenolic compounds ferulic acid and $p$-coumaric acid on the cell cycle of Caco-2 cells. Nutr Cancer 63: 611622. DOI: 10.1080/01635581.2011.538486. 
Jemal A, Bray F, Melisa M, Ferlay J, Ward E, Forman D. 2011. Global cancer statistics. CA Cancer J Clin 61: 69-90. DOI: 10.3322/caac.2 0107.

Juliani, Yuliana ND, Budijanto S, Wijaya $\mathrm{CH}$, Khatib A. 2016. Senyawa inhibitor alfa-glukosidase dan antioksidan dari kumis kucing dengan pendekatan metabolomik berbasis FTIR. J Teknol Industri Pangan 27: 17-30. DOI: 10.6066/jtip. 2016.27.1.17.

Kuo PC, Liu HF, Chao Jl. 2004. Survivin and P53 modulate quercetin-induced cell growth inhibition and apoptosis in human lung carcinoma cells. J Biol Chem 279: 55875-55885. DOI: 10. 1047/jbc.M407985200.

Leguizamón C, Weller CL, Schlegel VL, Carr TP. 2009. Plant sterol and policosanol characterization of hexane extracts from grain sorghum, corn, and their DDGS. J Am Oil Chem Soc 86: 707-716. DOI: 10.1007/s11746-009-1398-z.

Menéndez-Carreño M, Steenbergen H, Janssen HG. 2012. Development and validation of a comprehensive two-dimensional gas chromatographymass spectrometry method for the analysis of phytosterol oxidation products in human plasma. Anal Bioanal Chem 402: 2023-2032. DOI: 10.1007/s00216-011-5432-2.

N'Dri D, Mazzeo T, Zaupa M, Ferracane R, Fogliano V, Pellegrini N. 2013. Effect of cooking on the total antioxidant capacity and phenolic profile of some whole-meal African cereals. J Sci Food Agric 93: 29-36. DOI: 10.1002/jsfa.5837.

Pop RM, Buzoianu AD, Raţi IV, Socaciu C. 2014. Untargeted metabolomics for sea buckthorn (Hippophae rhamnoides ssp. carpatica) berries and leaves: fourier transform infrared spectroscopy as a rapid approach for evaluation and discrimination. Not Bot Horti Agrobo 42: 545550. DOI: 10.1583/nbha4229654.

Sadek NF, Yuliana ND, Prangdimurti E, Priyosoer yanto BP, Budijanto S. 2016. Potensi beras analog sebagai alternatif makanan pokok untuk mencegah penyakit degeneratif. J Pangan 25: 61-70.

Verpoorte R, Choi YH, Kim HK. 2005. Ethnopharmacology and systems biology: A perfect holistic match. J Ethnopharmacol 100: 53-56. DOI: 10. 1016/j.jep.2005.05.033.

Wu Li, Huang Z, Qin P, Ren G. 2013. Effects on processing on phytochemical profiles and biological activities for production of sorghum tea. Food Res Int 53: 678-685. DOI: 10.1016/j.food res.2012.07.062.

Yang $\mathrm{H}$, Yan F, Wu D, Huo M, Li J, Cao Y, Jiang Y. 2010. Recovery of phytosterols from waste residue of soybean oil deodorizer distillate. Bioresour Technol 101: 1471-1476. DOI: 10.1016/j. biortech.2009.09.019.

Yuliana ND, Rosa D, Budijanto S, Verpoorte R, Choi $\mathrm{YH}$. 2014. Identification of adenosine A1 receptor ligands from Morus alba L. stem bark by NMR metabolomics approach. Int Food Res J 21: 1067-1071.

Yusof NA, Isha A, Ismail IS, Khatib A, Shaari K, Abas F, Rukayadi Y' 2015. Infrared-metabolomics approach in detecting changes in andrographis paniculata metabolites due to different harvesting ages and times. J Sci Food Agr 95: 2533-2543. DOI: 10.1002/jsfa.6987.

Zbasnik R, Carr T, Weller C, Hwang KT, Wang L, Cuppett S, Schlegel V. 2009. Antiproliferation properties of grain sorghum dry distiller's grain lipids in caco-2 cells. J Agric Food Chem 57: 10435-10441. DOI: 10.1021/jf902136p. 